\title{
VARIABILITAS MORFOLOGI Rhizoctonia solani PENYEBAB PENYAKIT HAWAR PELEPAH PADI DI SULAWESI SELATAN
}

\section{Morphological Variability of Rhizoctonia Solani Causes of Rice Sheath Blight Disease In South Sulawesi}

\author{
P. Hamzah ${ }^{1}$, S. Subandiyah ${ }^{2}$, A. Wibowo ${ }^{3}$, dan A. Farhanah ${ }^{1}$ \\ ${ }^{1}$ Jurusan Pertanian, Politeknik Pembangunan Pertanian Gowa \\ ${ }^{2}$ Program Studi Bioteknologi, Sekolah Pascasarjana, Universitas Gadjah Mada \\ ${ }^{3}$ Jurusan Proteksi Tanaman, Fakultas Pertanian, Universitas Gadjah Mada \\ e-mail: pratiwi.hamzah.92@gmail.com
}

Received: 12 Maret 2021; Accepted: 25 Mei 2021; Published: 25 Juni 2021

\begin{abstract}
ABSTRAK
Rhizoctonia solani merupakan salah satu patogen penting penyebab penyakit hawar pelepah pada padi yang dapat hidup di tanaman maupun di tanah. Patogen ini menyebabkan penurunan kualitas dan kuantitas hasil panen padi. Variabilitas $R$. solani yang tinggi menyulitkan identifikasi dan pengendaliannya. Oleh karena itu patogen ini menjadi penting untuk dikaji. Tiga belas isolat $R$. solani berhasil diisolasi dari enam kabupaten di Provinsi Sulawesi Selatan dengan tujuan mempelajari variabilitas patogen berdasarkan karakter morfologinya. Hasil analisis klaster berdasakan morfologi menunjukkan variabilitas dengan kisaran koefisien similaritas 0,47-1,00. Semakin tinggi koefisien similaritas, semakin banyak klaster yang dapat terbentuk. Berdasarkan klasterisasi morfologinya, , ketiga belas isolat terkelompok menjadi dua kelompok utama. Isolat dari Kabupaten Maros tergabung dalam satu kelompok; isolat dari Kabupaten Pangkep, Barru, Pare-pare, Sidrap dan Soppeng tergabung dalam kelompok lainnya. Hasil penelitian ini diharapkan dapat menjadi dasar ilmiah dalam langkah-langkah teknis implementasi Good Agricultural Practice (GAP) di Sulawesi Selatan.
\end{abstract}

Kata kunci: Morfologi, padi, Rhizoctonia solani, variabilitas

\begin{abstract}
Rhizoctonia solani is one of the important pathogens causing midrib blight in rice that can live in plants and in the soil. This pathogen causes a decrease in the quality and quantity of rice yields. The high variability of $\mathrm{R}$. solani made it difficult to identify and control it. Therefore, this pathogen is important to study. Thirteen isolates of $\mathrm{R}$. solani were isolated from six districts in South Sulawesi Province with the aim of studying the variability of pathogens based on their morphological characters. The results of cluster analysis based on morphology showed variability with a similarity coefficient range from 0.47 to 1.00. The higher the similarity coefficient, the more clusters that can be formed. Based on their morphological clustering, the thirteen isolates were grouped into two main groups. Isolates from Maros district joined in one group; isolates from Pangkep, Barru, Pare-pare, Sidrap and Soppeng districts were part of another group. The results of this study are expected to become a scientific basis in the technical steps for implementing Good Agricultural Practice (GAP) in South Sulawesi.
\end{abstract}

Keywords: Morphology, rice, Rhizoctonia solani, variability 


\section{PENDAHULUAN}

Good Agriculture Practice (GAP) adalah cara pelaksanaan budi daya tanaman pertanian (pangan, buah dan sayur) dan perkebunan secara baik, benar dan tepat mencakup kegiatan pratanam hingga penanganan pascapanen. Salah satu tujuan penerapan GAP yaitu meningkatkan produksi dan produktivitas. Jika produksi dan produktivitas hasil panen meningkat maka rantai nilai hasil panenpun dapat ikut meningkat. Oleh karena itu, penting untuk mengkaji hal preventif dalam mengurangi produksi dan produktivitas tanaman padi. Salah satunya adalah penyakit hawar pelepah padi yang disebabkan oleh Rhizoctonia solani.

Rhizoctonia solani [Kuhn] merupakan jamur patogen yang terdistribusi di tanah secara global. $R$. solani dapat menyebabkan penyakit hawar pelepah pada beberapa tanaman termasuk pada padi. Jamur $R$. solani yang dapat menginfeksi tanaman padi dimasukkan ke dalam sub grup AG1-IA. Hawar pelepah padi dengan cepat dapat berkembang parah menjadi faktor utama penentu keberhasilan panen di beberapa negara seperti China, Jepang, Filipina dan negara di Asia (Cumagun et al., 2018). Hawar pelepah berkembang baik di semua lokasi penanaman padi, baik pada ekosistem padi dataran tinggi maupun dataran rendah di Indonesia (Nuryanto, 2011).

Identifikasi dan klasifikasi $R$. solani dilakukan berdasarkan morfologi, patogenesitas, dan kemampuan hifa jamur tersebut melakukan fusi yang disebut anastomosis. Seiring pekembangan teknologi, identifikasi jamur tersebut juga dilakukan secara molekuler. Variabilitas jamur $R$. solani pada padi baik secara morfologi, patogenisitas dan genetiknya juga telah dilakukan di berbagai negara seperti India (Guleria, 2007), China (Shu, 2014), Vietnam (Matsumoto \& Chuong, 2014), Bangladesh (Moni et al., 2016), dan lain-lain.

Penelitian mengenai variabilitas morfologi yang berkaitan dengan patogenesitas $R$. solani masih terus dikaji sehingga informasi tersebut diharapkan dapat menjadi sumbangan besar dalam perumusan strategi yang paling tepat termasuk pengembangan ke arah rekayasa genetik dalam upaya pengendalian jamur $R$. solani di Indonesia. Tujuan penelitian ini yaitu mengetahui variabilitas morfologi isolat Rhizoctonia solani penyebab hawar pelepah padi dari beberapa daerah produksi beras di Sulawesi Selatan. Hasil penelitian ini diharapkan dapat menjadi dasar ilmiah dalam langkah-langkah teknis implementasi Good Agricultural Practice (GAP) di Sulawesi Selatan.

\section{METODE PENELITIAN}

\section{Isolasi, Identifikasi Morfologi dan Pemeliharaan Kultur Patogen}

Pengambilan sampel dilakukan di enam kabupaten di Sulawesi Selatan yaitu Kabupaten Maros, Kabupaten Pangkep, Kabupaten Barru, Kabupaten Pare-Pare, Kabupaten Soppeng dan Kabupaten Sidrap (Tabel 1). Jamur $R$. solani diisolasi dari tanaman bergejala hawar pelepah padi yang dikumpulkan dari beberapa sawah di keenam kabupaten tersebut. Daerah pelepah yang mengandung bagian bergejaladan yang tidak, dipotong sepanjang 3-4 mm, lalu disterilisasi dalam larutan hipoklorit 1\% selama 3-5 menit, dibilas 2-3 kali dengan air steril, dikeringkan lalu secara aseptik ditempatkan pada media potato dextrose agar (PDA). Inkubasi dilakukan selama dua hari pada suhu $28 \pm 2^{\circ} \mathrm{C}$. Ujung-ujung hifa yang berasal dari potongan-potongan jaringan terputus dipindahkan ke PDA dalam cawan Petri untuk pemurnian dan pertumbuhan lebih lanjut dari patogen $R$. solani.

Identifikasi morfologi jamur $R$. solani dilakukan secara makroskopis dan mikroskopis. Pengamatan makroskopis meliputi pengamatan terhadap miselium dan keberadaan sklerotia, sedangkan pengamatan secara mikroskopis meliputi pengamatan terhadap karakteristik percabangan tegak lurus dan sekat yang diamati menggunakan mikroskop (Guleria, et al., 2007). Sklerotia tunggal dari semua isolat dikultur secara terpisah pada media agar miring dalam tabung reaksi pada $10 \pm 2^{\circ} \mathrm{C}$ sebagai pemeliharaan stok dari patogen ini (Mughal et al., 2017).

\section{Variabilitas Morfologi $R$. solani}

Dilakukan pengamatan secara kuantitatif dan kualitatif. Pengamatan kuantitatif berupa pengukuran diameter koloni, laju pertumbuhan dan diameter hifa mengikuti metode yang dilakukan Guleria et al. (2007) dengan sedikit modifikasi. Sedangkan pengamatan kualitatif dilakukan setelah 15 hari inkubasi. Karakteristik yang diamati dari miselium yaitu warna depan 
dan belakang, kualitas aerial miselium, serta keberadaan hifa di bagian penutup petri.

Selain miselium, diamati pula delapan karakteristik sklerotia yang terbentuk berupa warna, bentuk, eksudat di permukaan sklerotia, keberadaan sklerotia di tutup cawan petri, kualitas, tipe serta pola dan kepadatan penyebaran sklerotia. Variabilitas morfologi $R$. solani dianalisis menggunakan software NTSYS untuk dibuat dendrogram.

Tabel 1 Informasi kode, daerah asal padi sumber isolat

\begin{tabular}{ccc}
\hline No & Kode Isolat & Kabupaten \\
\hline 1 & MRS A2 & Maros \\
2 & MRS A3 & Pangkep \\
3 & PKP A1 & \\
4 & PKP A2 & Barru \\
5 & BRU A1 & \\
6 & BRU A2 & Pare Pare \\
7 & BRU A3 & \\
8 & PAR A1 & Soppeng \\
9 & PAR A2 & \\
10 & SPG A1 & Sidrap \\
11 & SPG A2 & \\
12 & SDP A1 & \\
13 & SDP A2 &
\end{tabular}

\section{HASIL DAN PEMBAHASAN}

\section{Identifikasi Morfologi dan Pemeliharaan Kultur Patogen}

Sejumlah tiga belas isolat jamur berhasil diisolasi dari enam kabupaten di Provinsi Sulawesi Selatan. Identifikasi awal dilakukan berdasarkan karakter morfologi menunjukkan bahwa ketigabelas isolat tersebut memiliki miselium yang menyerupai serabut benang tipis putih dan dapat berubah warna hingga cokelat tua, sesuai dengan yang dinyatakan oleh Alexopoulos and Mims (1996). Miselium tersebut juga membentuk sklerotia yaitu struktur agregat kecil padat dan menyebar di permukaan miselium. Secara mikroskopis terlihat hifa dengan percabangan tegak lurus, mempunyai sekat, serta tidak ditemukan struktur reproduksi seksual dan tidak ada sambungan apit. Oleh karena itu, ketigabelas isolat yang telah diisolasi teridentifikasi sebagai $R$. solani berdasarkan karakter morfologinya tersebut (Gambar 1).
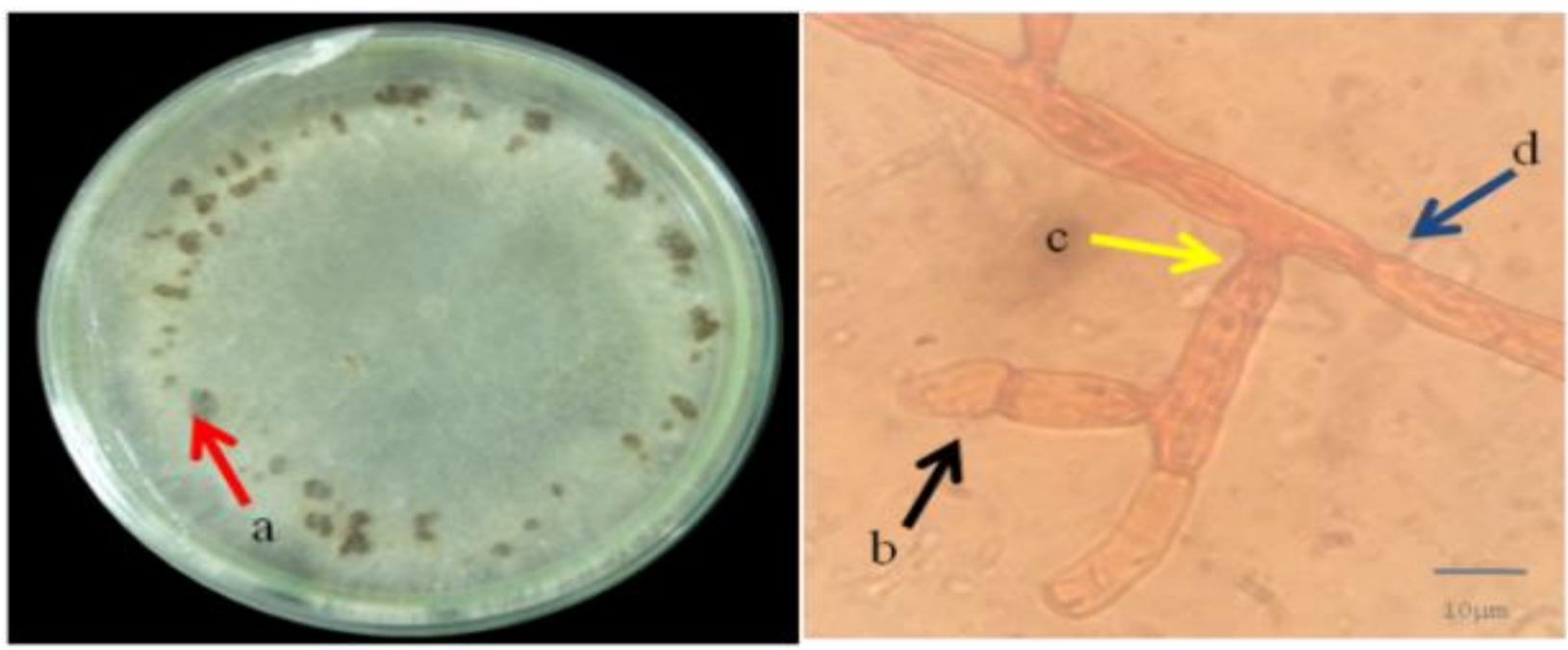

Gambar 1. Koloni R. solani secara makroskopis (kiri) dan mikroskopis (kanan). Sklerotia (a), sel monilioid (b), percabangan hifa (c) dan sekat (d) 


\section{Variabilitas Morfologi R. solani}

Hasil pengamatan kuantitatif berupa pengukuran diameter koloni dan laju pertumbuhan menunjukkan hasil yang beragam. Guleria et al. (2007), menggolongkan laju pertumbuhan jamur $R$. solani berdasarkan diameter koloni menjadi 3 grup. Grup 1 yaitu isolat-isolat yang pertumbuhannya lambat dengan laju kurang dari $16 \mathrm{~mm} / \mathrm{hari}$. Grup 2 yaitu isolat yang pertumbuhannya sedang dengan laju antara $16-21 \mathrm{~mm} /$ hari serta grup 3 yaitu isolat dengan pertumbuhan cepat ditandai dengan laju lebih dari $21 \mathrm{~mm} / \mathrm{hari}$.

Berdasarkan penggolongan tersebut, hasil pengamatan menunjukkan bahwa isolat pada penelitian ini terbagi menjadi 3 kelompok. Isolat MRS A2 dari Kabupaten Maros, Sulawesi Selatan merupakan isolat dengan laju pertumbuhan terendah yaitu sebesar $15,44 \mathrm{~mm} /$ hari sehingga digolongkan kedalam grup 1. Isolat yang tergolong grup 2 dengan laju pertumbuhan sedang, teramati pada isolat dengan laju pertumbuhan 18,00 mm/hari yaitu isolat MRS A3 dari Maros. Sebanyak 11 isolat lainnya digolongkan ke grup 3 karena laju pertumbuhannya yang tinggi yaitu antara 28,89 dan $30 \mathrm{~mm} /$ hari. Sebanyak 5 dari 11 isolat yang tergolong grup 3 tersebut merupakan isolat dengan laju pertumbuhan tertinggi yaitu sebesar $30 \mathrm{~mm} /$ hari. Hal tersebut dikarenakan miselium dari dua puluh lima isolat tersebut telah memenuhi permukaan media di cawan petri pada hari ke-3 atau setelah 72 jam. Hasil pengamatan diameter hifa jamur Rhizoctonia solani yang telah diisolasi menunjukkan bahwa hifa jamur tersebut memiliki diameter antara 6,47 hingga 10,3 $\mu \mathrm{m}$. Data diameter koloni, laju pertumbuhan dan diameter hifa disajikan pada Tabel 2.

Tabel 2. Diameter koloni, laju pertumbuhan dan diameter hifa

\begin{tabular}{|c|c|c|c|c|c|c|c|}
\hline \multirow{2}{*}{ No } & \multirow{2}{*}{ Kode Isolat } & \multicolumn{3}{|c|}{ Diameter Koloni $(\mathrm{mm})$ setelah } & \multirow{2}{*}{\multicolumn{2}{|c|}{$\begin{array}{l}\text { laju pertumbuhan }{ }^{\mathrm{a}} \\
(\mathrm{mm} / \mathrm{hari})\end{array}$}} & \multirow{2}{*}{$\begin{array}{l}\text { diameter hifa } \\
\qquad(\mu \mathrm{m})\end{array}$} \\
\hline & & 24jam & 48jam & 72jam & & & \\
\hline 1 & MRS A2 & 15,67 & 26,33 & 46,33 & 15,44 & $\mathrm{a}$ & 8,03 \\
\hline 2 & MRS A3 & 14,67 & 32,00 & 54,00 & 18,00 & bc & 7,13 \\
\hline 3 & PKP A1 & 15,33 & 42,33 & 86,67 & 28,89 & d & 7,37 \\
\hline 4 & PKP A2 & 21,33 & 68,00 & 88,67 & 29,56 & $\mathrm{~d}$ & 8,33 \\
\hline 5 & BRU A1 & 23,67 & 78,67 & 90,00 & 30,00 & $\mathrm{~d}$ & 6,73 \\
\hline 6 & BRU A2 & 17,33 & 58,00 & 88,33 & 29,44 & $\mathrm{~d}$ & 9,77 \\
\hline 7 & BRU A3 & 22,00 & 79,00 & 90,00 & 30,00 & $\mathrm{~d}$ & 8,53 \\
\hline 8 & PAR A1 & 25,33 & 81,67 & 90,00 & 30,00 & $\mathrm{~d}$ & 10,3 \\
\hline 9 & PAR A2 & 27,67 & 74,67 & 88,33 & 29,44 & d & 8,06 \\
\hline 10 & SPG A1 & 36,67 & 82,33 & 88,33 & 29,44 & d & 7,30 \\
\hline 11 & SPG A2 & 22,67 & 73,67 & 89,00 & 29,67 & d & 6,47 \\
\hline 12 & SDP A1 & 23,67 & 82,00 & 90,00 & 30,00 & d & 8,90 \\
\hline 13 & SDP A2 & 35,00 & 89,00 & 90,00 & 30,00 & d & 9,13 \\
\hline
\end{tabular}

Isolat dan jenis media yang digunakan akan mempengaruhi diameter hifa jamur (Soenartiningsih, 2015). Hifa tersebut dapat membentuk miselium yang terdiri dari sel-sel monilioid yang berperan dalam pembentukan sklerotia (Ou, 1985). Sklerotia berperan dalam ketahanan $R$. solani di lapangan (Feng et al., 2017). Sklerotia yang terbentuk dari jamur tular tanah dapat bertahan di dalam tanah selama 6-7 tahun (Magenda et al., 2011). Pengamatan secara kuantitatif ini belum cukup untuk mencirikan jamur $R$. solani sehingga dilakukan pengamatan selanjutnya secara kualitatif berdasarkan beberapa karakter morfologi $R$. solani. Setelah inkubasi selama 15 hari, koloni isolat jamur tampak depan dan belakang memliki ragam warna dari bening hingga cokelat tua. seluruh isolat memiliki aerial miselium dengan kualitas sebagian besar isolat terisi penuh dan tebal, serta ada di tutup cawan petri.

Tipe sklerotia yang terbentuk pada isolatisolat yang diamati ada tiga tipe yaitu tipe mikro, makro dan keduanya. Sedangkan warnanya beragam mulai dari krem hingga coklat tua. Bentuk sklerotia ada yang superfisial (dangkal) dan ada yang tidak beraturan dengan permukaan berbintik. Pola penyebaran sklerotia dibedakan ke dalam kategori scattered, centrally consentrated, 
consentrated at rim, concentris rings dan ring toward periphery. Sedangkan kepadatannya dibedakan menjadi sparse dan enourmous (Jayaprakashvel \& Mathivanan, 2012).

Berdasarkan hasil penelitian, empat isolat menghasilkan sklerotia tipe makro, dua isolat menghasilkan tipe mikro, tujuh isolat menghasilkan keduanya. Sebagian besar isolat memiliki tipe sklerotia makro, berwarna cokelat, tidak beraturan dengan permukaan berbintik serta memiliki eksudat di permukaannya. Sklerotia juga terbentuk di bagian tutup cawan petri. Pola dan kepadatan penyebaran sklerotia juga beragam, namun sebagian besar acak dan jarang. Beberapa isolat juga menghasilkan sklerotia tipe mikro dimana pola dan kepadatan penyebarannya membentuk cincin di tengah dan padat. Selanjutnya hasil pengamatan berdasarkan karakter morfologi tersebut dianalisis klaster menggunakan software NTSYS untuk melihat variabilitasnya (Gambar 2). Dendrogram tersebut menunjukkan bahwa berdasarkan variabilitas morfologi koloni, 13 isolat $R$. solani AG1-IA terkelompok pada koefisien similaritas dengan kisaran 0,47-1,00. Semakin tinggi nilai koefisien similaritas maka semakin banyak pengelompokkan yang terjadi. Pengelompokan pada nilai koefisien similaritas sebesar 0,47 dapat mengelompokkan isolat $R$. solani menjadi dua klaster utama.

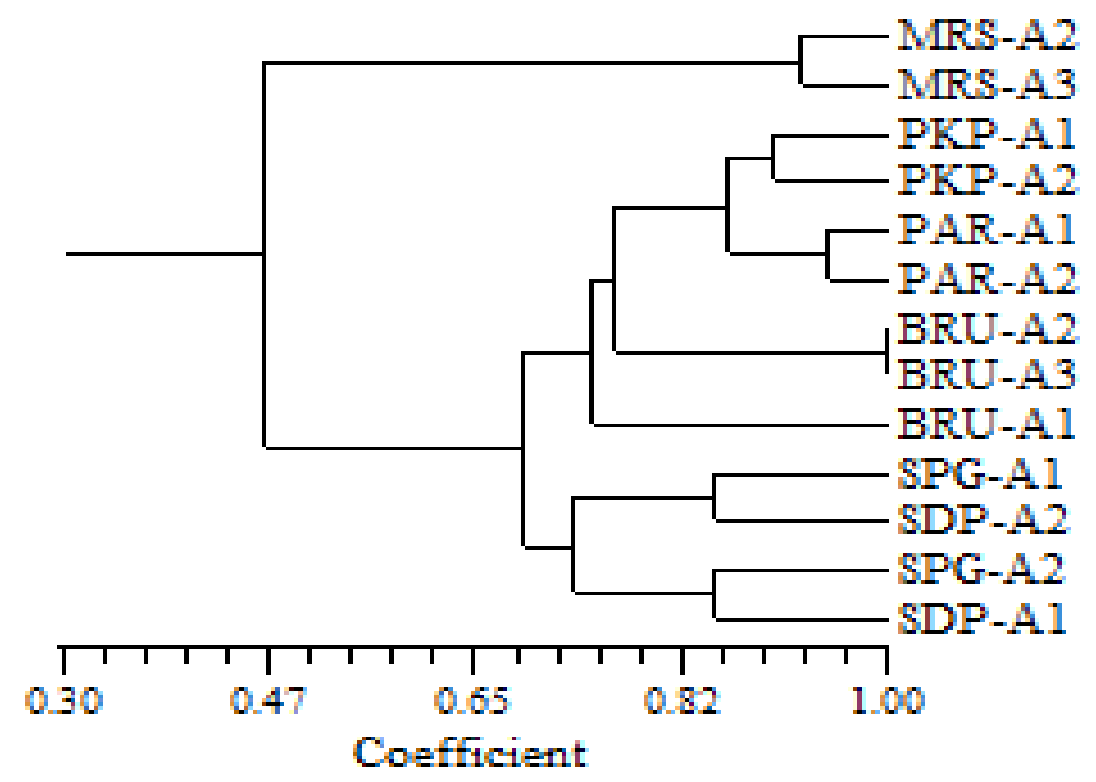

Gambar 2. Dendrogram variabilitas morfologi Rhizoctonia solani AG1-IA berdasarkan analisis klaster menggunakan software NTSYSpc dan metode klaster UPGMA.

Dendrogram berdasarkan karakter morfologi ini mengelompokkan isolat dari kabupaten Maros ke dalam satu klaster, sedangkan isolat yang berasal dari kabupaten lainnya terkelompok dalam klaster kedua pada koefisien similaritas 0,47. Berdasarkan dendrogram tersebut, dua isolat yang berasal dari kabupaten Barru yaitu isolat BRU A2 dan BRU A3 memiliki nilai similaritas $100 \%$. Hal tersebut mengindikasikan bahwa isolat tersebut ada kemungkinan merupakan isolat yang sama. Dendrogram ini juga menunjukkan bahwa isolat yang berasal dari kabupaten yang sama cenderung memiliki kemiripan morfologi. Hal serupa juga dinyatakan oleh Das et al. (2019) dimana pengelompokan morfologis $R$. solani dari bit di Nebraska sebagian besar menunjukkan korelasi dalam isolat dari populasi yang sama.

\section{KESIMPULAN}

Analisis variabilitas morfologi $R$. solani di Beberapa Kabupaten di Sulawesi Selatan telah dilakukan. Hasil penelitian ini menunjukkan bahwa isolat yang berasal dari kabupaten yang sama cenderung memiliki kemiripan morfologi. Meskipun demikian, variabilitas $R$. solani tetap perlu dikaji lagi secara mendalam. Hasil penelitian ini diharapkan dapat menjadi dasar ilmiah dalam langkah-langkah teknis pengendalian berkelanjutan R.solani sebagai 
implementasi Good Agricultural Practice (GAP) berkelanjutan di Sulawesi Selatan sehingga jangka panjangnya diharapkan dapat menstabilkan produksi dan produktivitas padi agar dapat meningkatkan nilai rantai tanaman padi dan memenuhi kebutuhan seluruh rakyat Indonesia secara berkelanjutan.

\section{DAFTAR PUSTAKA}

Alexopoulos, C.J., C.W.Mims \& M. Blackwell. 1996. Introductory Mycology, John Wiley \& Sons, Inc., Canada.

Cumagun, Christian Joseph Rili et al. 2018. Population genetic structure of the sheath blight pathogen Rhizoctonia solani AG-1 IA from rice fields in China, Japan and the Philippines. Acta Scientiarum. Agronomy, v. 42, e42457, 2020.

Feng et al. 2017. Survival of Rhizoctonia solani AG-1 IA, the Causal Agent of Rice Sheath Blight, under Different Environmental Conditions. J Phytopathol165 (2017) 44-52.

Guleria S, R. Aggarwal,T. S. Thind and T. R. Sharma. 2007. Morphological and Pathological Variability in Rice Isolates of Rhizoctonia solani and Molecular Analysis of their Genetic Variability. $J$. Phytopathology 155, 654-661.

Jayaprakashvel M and N. Mathivanan, 2012, "Morphological and pathological variations of rice sheath blight inciting south Indian Rhizoctonia solani isolates", Archives of Phytopathology and Plant Protection, 45:4, 455-467.

Magenda, S., F. Kandao, S. Umboh. 2011. Karakteristik Isolat Jamur Sclerotium rolfsii dari Tanaman Kacang Tanah (Arachis Hypogaea Linn). J Bioslogos 1(1): 17.
Matsumoto M and Chuong H.V. 2014. Genetic Characterization Of The Rice Sheath Blight Pathogen Rhizoctonia Solani AG1-IA In North Vietnam By Rep-PCR And Sequence Analysis. Journal of Plant Pathology, 96(2), 377-380.

Moni, ZR, et al., 2016. Morphological and Genetical Variability among Rhizoctonia solani Isolates Causing Sheath Blight Disease of Rice. Rice Science, 23(1): 4250.

Mughal, Mohammad Najeeb, Sabiya Bashir, Nazir A. Bhat and Bhat, K.A. 2017. Cultural and Morphological Variability and Identification of Anastomosis Group of Rhizoctonia solani (Thanatephorus cucumeris) Causing Sheath Blight of Rice in Kashmir. Int.J.Curr.Microbiol.App.Sci. 6(11): 3787-

Nuryanto, Bambang. 2011. Varietas, Kompos dan Cara Pengairan sebagai Komponen Pengendali Penyakit Hawar Upih. Disertasi. Program Pascasarjana, Universitas Gadjah Mada, Yogyakarta. $126 \mathrm{p}$.

Shu, Can-Wei, Cheng-Jia Zou, Jie-Ling Chen, Fang Tang, Run-Hua Yi \& Er-Xun Zhou. 2014. Genetic diversity and population structure of Rhizoctonia solani AG-1 IA, the causal agent of rice sheath blight, in South China. Canadian Journal of Plant Pathology, 36:2, 179-186.

Soenartiningsih, et al. 2015. Cendawan Tular Tanah ( $R$ solani) Penyebab Penyakit Busuk Pelepah pada Tanaman Jagung dan Sorgum dengan Komponen Pengendaliannya. Iptek Tanaman Pangan Vol. 10 No 22015. 